\title{
The Behavioural and Morphometric Features of West African Manatee: Trichechus senegalensis in a Semi-Wild Environment
}

\section{Esenowo IK*, Akpan UA and Egwali EC}

Department of Zoology, University of Uyo, Akwa Ibom, Nigeria

“Corresponding author: Esenowo IK, Department of Zoology, University of Uyo, Akwa lbom, Nigeria, Tel: 23481461298; E-mail: imehesenowo@yahoo.com Rec date: Feb 04, 2014; Acc date: May 19, 2014; Pub date: May 27, 2014

Copyright: () 2014 Esenowo IK et al. This is an open-access article distributed under the terms of the Creative Commons Attribution License, which permits unrestricted use, distribution, and reproduction in any medium, provided the original author and source are credited.

\begin{abstract}
The behavioural and morphometric features of West Africa manatee; Trichechus senegalensis, in a semi-wild environment was study from July $1^{\text {st }} 2008$ to November $30^{\text {th }} 2008$. Surface water was measured to determine the Physico-chemical parameters of the stream. Mean values of surface water temperature of $26.56 \pm 1.08^{\circ} \mathrm{C} ; \mathrm{pH}, 6.47$ \pm 0.25 ; Free carbon dioxide, $8.83 \pm 1.44 \mathrm{mg} / \mathrm{L}$; total alkalinity, $10.35 \pm 1.85 \mathrm{mg} / \mathrm{L}$; Dissolved Oxygen, $7.35 \pm 1.42$ $\mathrm{mg} / \mathrm{L}$ and Biological Oxygen Demand (BOD) $2.41 \pm 0.47 \mathrm{mg} / \mathrm{L}$ were within stipulated ranged as safe for aquatic organism. Eleven Macrophytes belonging to eight families were fed to the manatee daily. The morphometric measurement showed total length $192 \mathrm{~cm}$, standard length $152 \mathrm{~cm}$, body weight $265 \mathrm{~kg}$, fluke width $36 \mathrm{~cm}$, flipper length $36 \mathrm{~cm}$, head length $34 \mathrm{~cm}$, girth at umbilicus $120 \mathrm{~cm}$, girth at genital pore $82 \mathrm{~cm}$, girth at anus $64 \mathrm{~cm}$. The results indicate that the semi-wild environment provides favourable conditions for the survival of the manatee.
\end{abstract}

Keywords: Trichechus senegalensis; Behavioural; Morphometric and Semi-wild environment

\section{Introduction}

African Manatees are heavy and fusiform in shape. Adults are 3 to 4 $\mathrm{m}$ in length and weigh less than $500 \mathrm{~kg}$. The horizontally flattened tail is spatulate and the forelimbs are paddle like with nails on the dorsal surface. The skin is finely wrinkled throughout and grayish-brown in color. Fine, colorless hairs are sparsely distributed over the body and stout bristles are located on the upper and low axillary mammae. Eyes are small, close and eyelashes are absent. The ears are pinnae [1].

The West African manatee; (Trichechus senegalensis), belongs to one of only three living species in the order Sirenia [2]. It is found in the coastal areas of tropical and subtropical western African. The second species, Amazonian manatee ( $T$. inunguis) is found only in freshwater areas of the Amazon basin, while the third; the West Indian manatees (T. manatus) are found from the southern United States to the north-eastern coast of Brazil [3].

The West African manatee is an aquatic mammal with a robust, fusiform body that is compressed dorso-ventrally. Although the West Indian manatee and Amazonian manatee appear grey-brown and with white/pink patches on the belly and chest, their thick tough skin is sparsely covered with small thick hair. The body of the manatee has no hind limbs, but a paddle-like forelimbs or flippers with three to four nails that are present on the dorsal surface of each flipper. The body tapers to a spatulate, dorso-ventrally flattened tail [4].

The West African manatees live in quite coastal areas, large rivers and lakes that connect with rivers [5]. Manatees are herbivores that feed on a wide variety of submerged and emergent vegetation [6]. The distribution and abundance of manatees are affected by water temperature and availability of aquatic vegetation [7]. Antonion et al. [8] reported that manatees are restricted to rivers and estuaries with temperature of $24.4^{\circ} \mathrm{C}$, while Perrin et al. [9] reported that the West African manatees are limited to waters of $18^{\circ} \mathrm{C}$ and $27^{\circ} \mathrm{C}$. Additionally,
Deutsch et al. [7] also reported that increase in salinity greatly influence the distribution of manatees and also reproduction, feeding and calving.

The adult manatees are between 3-5 $\mathrm{m}$ in length, weight $363-460 \mathrm{~kg}$, flippers length $0.58 \mathrm{~m}$ and circumference of body $2.25 \mathrm{~m}$ [10]. However, studies on the Manatees have only been carried out in the natural environment in the creeks of the Niger Delta region of Nigeria [5] and with little or no study of the mammal in a semi wild environment, hence, the need for the present study.

\section{Materials and Methods}

\section{Study Area}

The study area lies between latitude $4^{\circ} 50^{1}$ and $5^{\circ} 00^{1} \mathrm{~N}$ and longitude $7^{\circ} 45^{1}$ and $8^{\circ} 00^{1}$. The semi-wild environment is characterised with natural flowing streams, a tributary of the Eyong River in Akwa Ibom State, Nigeria. It is characterized with rainy season which begins in April and lasts till early November and a brief dry season which starts from November and ends in March. Relative humidity is high in the rainy seasons and low in the dry season. The Little stream Farm support subsistence crop farming such as Abelmoschus esculentus (Okra), Zea mays (Corn), Manihot esculentus (Cassava), Telfauria occidentalis (Pumpkin), Talinum triangulare (Water leaf) and Cucueropsis mannii (Melon). The local indigenes involved in activities such as artisanal fishing, using fish nets and hook and lines, illegal sand mining and hunting of small mammals in the Little Stream Farm (Figure 1).

The Physico-chemical parameters measured included; water temperature, hydrogen ion concentration $(\mathrm{pH})$, free carbon dioxide, total alkalinity, Dissolved Oxygen (DO) and Biological Oxygen Demand (BOD). The water temperature was measured in-situ using Mercury in glass thermometer calibrated in degree centigrade; $\mathrm{pH}$ was measured using electronic $\mathrm{pH}$ meter Kent 7020. Dissolved Oxygen (DO), Biological Oxygen Demand (BOD), total alkalinity and free 
Citation: Esenowo IK, Akpan UA, Egwali EC (2014) The Behavioural and Morphometric Features of West African Manatee: Trichechus senegalensis in a Semi-Wild Environment. J Biodivers Endanger Species 2: 129. doi:10.4172/2332-2543.1000129

Page 2 of 4

carbon dioxide were measured titrimetrically according to APHA [11] and recorded as $\mathrm{mg} / \mathrm{L}$.

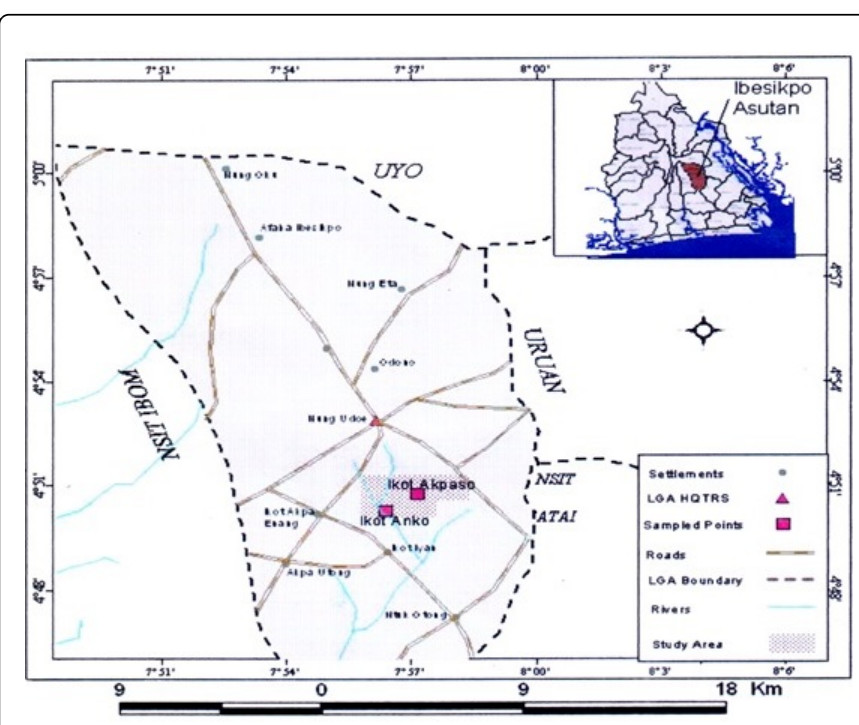

Figure 1: Map showing study area.

The manatee was captured in the Wild with fishing net and transported to a semi-wild environment, occupied by submerged and emergent aquatic plant such as water lily (Nymphaea odorata). The canal was measured to be $99.625 \mathrm{~m}^{2}$ in length, $5.4 \mathrm{~m}^{2}$ in width and 1.2 $\mathrm{m}^{2}$ in depth.

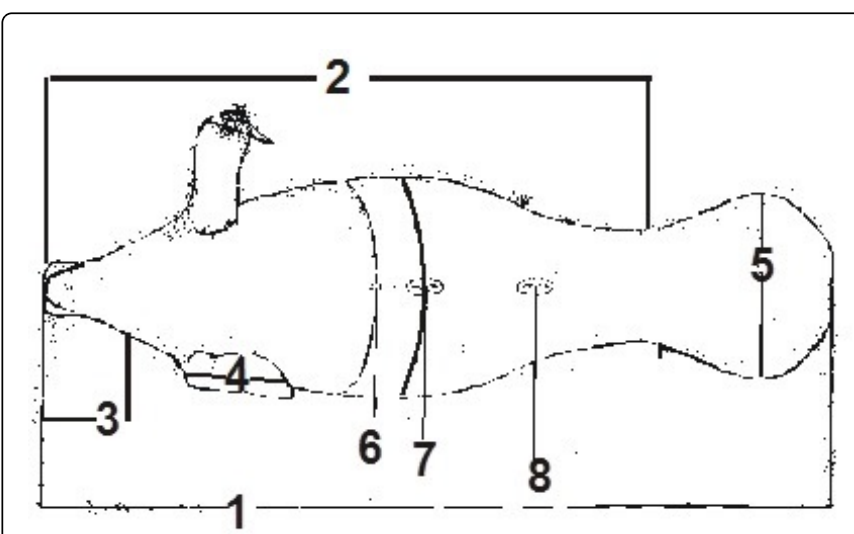

Figure 2: Diagram showing morphometric measurement of the manatee. (Keys: 1) Total Length (TL), 2) Standard length (SL), 3) Head length (HL), 4) Flipper Length (FL), 5) Fluke Width (FW), 6) Girth at umbilicus, 7) Girth at genital pore, 8) Girth at anus

The manatee behaviours where observed using the focal animal sampling method by Martin and Bateson et al. [12] from the hours of 7 am-7 pm: morning (7 am-10 am), noon (12 noon-3 pm) and late afternoon (4 pm-7 pm). The time intervals were taken using a Diamond mechanical stop watch and recorded in minutes. Plants harvested from the environment at designated locations, where introduced into the canal for the manatee to forage on. The morphometric feature of the manatee were measured and these included body weight $(\mathrm{kg})$, Total Length of manatee (TL), Standard
Length (SL), Flipper Length (FL), Head Length (HL), girth at umbilicus, girth at genital pore and anus, eye diameter, and fluke width. The eye diameter was measured using digital Vernier caliper while other lineal and girth measurements were recorded using tape metre and recorded in centimetre $(\mathrm{cm})$ (Figure 2).

\section{Results}

\section{Physico-chemical parameters}

The mean values and standard error of Physico-chemical parameter is shown in Table 1 , while Table 2 shows the different observed behaviours of the manatee in the semi-wild environment.

\begin{tabular}{|l|l|l|l|}
\hline Physico-chemical Parameters & August & October & November \\
\hline $\mathrm{pH}$ & $5.95 \pm 0.24$ & $6.23 \pm 0.46$ & $7.23 \pm 0.05$ \\
\hline Temperature $\left({ }^{\circ} \mathrm{C}\right)$ & $\begin{array}{l}27.00 \\
0.41\end{array}$ & $\begin{array}{l}26.05 \\
1.28\end{array}$ & $\begin{array}{l}26.62 \quad \pm \\
1.55\end{array}$ \\
\hline Free $\mathrm{CO}_{2}(\mathrm{mg} / \mathrm{L})$ & $8.40 \pm 1.25$ & $9.30 \pm 1.33$ & $8.80 \pm 1.74$ \\
\hline Total alkalinity (mg/L) & $10.5 \pm 0.70$ & $\begin{array}{l}10.52 \\
2.06\end{array}$ & $\begin{array}{l}10.02 \\
2.78\end{array}$ \\
\hline Dissolved oxygen (mg/L) & $6.52 \pm 0.22$ & $7.77 \pm 2.41$ & $7.77 \pm 1.62$ \\
\hline $\begin{array}{l}\text { Biochemical Oxygen Demand } \\
(\mathrm{mg} / \mathrm{L})\end{array}$ & $1.92 \pm 0.41$ & $2.9 \pm 0.08$ & $2.49 \pm 0.93$ \\
\hline
\end{tabular}

Table 1: Mean and standard error of Physico-chemical parameter measured during the study period

\begin{tabular}{|l|l|l|l|}
\hline S/no & Behaviour & Description & Time \\
\hline 1 & $\begin{array}{l}\text { Bottom Rest } \\
\text { (BR) }\end{array}$ & Resting and sleeping at the bottom of the canal & $\begin{array}{l}4: 05 \\
\text { min }\end{array}$ \\
\hline 2 & Mill (M) & Slow, non-directional travel in the same area. & - \\
\hline 3 & $\begin{array}{l}\text { Surface } \\
\text { feeding (SF) }\end{array}$ & $\begin{array}{l}\text { Feeding on the floating bundle of plants tied to } \\
\text { wooden poles in the water column of the canal. }\end{array}$ & - \\
\hline 4 & $\begin{array}{l}\text { Slow swim } \\
\text { SS) }\end{array}$ & $\begin{array}{l}\text { Steady movement in one direction at a slow to } \\
\text { moderate pace, using its flippers and tail to } \\
\text { steer itself. }\end{array}$ & $\begin{array}{l}1: 40 \\
\text { min }\end{array}$ \\
\hline 6 & $\begin{array}{l}\text { Fast Swim } \\
\text { FS) }\end{array}$ & $\begin{array}{l}\text { Steady movement in one direction at fast pace, } \\
\text { without using the flippers and tail to steer itself. }\end{array}$ & $\begin{array}{l}1: 05 \\
\text { min }\end{array}$ \\
\hline 7 & $\begin{array}{l}\text { Rest and } \\
\text { surface for air }\end{array}$ & $\begin{array}{l}\text { Submerged in the water column and surfacing } \\
\text { for air in-take while feeding. }\end{array}$ & $\begin{array}{l}\text { Submerged in the water column and surfacing } \\
\text { for air in-take while resting. }\end{array}$ \\
\hline 8 & $\begin{array}{l}\text { Bubble } \\
\text { min }\end{array}$ & $\begin{array}{l}\text { The manatee release air from nostrils without } \\
\text { min }\end{array}$ \\
\hline
\end{tabular}

Table 2: Observed behaviours of T. senegalensis, with time taken in the canal.

\section{Morphometric measurement}

The morphometric measurements of the manatee from wild environment (initial) and during the studies in the semi-wild environment (final) are shown in Table 3, while Table 4 shows plants species fed to the manatee. 


\begin{tabular}{|l|l|l|}
\hline Morphological Features & Initial measurement & Final Measurement \\
\hline Total length (TL) & $190 \mathrm{~cm}$ & $192 \mathrm{~cm}$ \\
\hline Fluke width (FW) & $34 \mathrm{~cm}$ & $36 \mathrm{~cm}$ \\
\hline Eye diameter (ED) & $34 \mathrm{~cm}$ & $36 \mathrm{~cm}$ \\
\hline Flipper length (FL) & $33 \mathrm{~cm}$ & $36 \mathrm{~cm}$ \\
\hline Standard length (SL) & $150 \mathrm{~cm}$ & $152 \mathrm{~cm}$ \\
\hline Head length (HL) & $33 \mathrm{~cm}$ & $34 \mathrm{~cm}$ \\
\hline Girth at umbilicus & $126 \mathrm{~cm}$ & $129 \mathrm{~cm}$ \\
\hline Girth at genital pore & $80 \mathrm{~cm}$ & $82 \mathrm{~cm}$ \\
\hline Girth at anus & $63 \mathrm{~cm}$ & $64 \mathrm{~cm}$ \\
\hline Body weight & $255 \mathrm{~kg}$ & $265 \mathrm{~kg}$ \\
\hline
\end{tabular}

Table 3: Morphometric measurement of T. senegalensis.

\begin{tabular}{|l|l|l|l|}
\hline Family & Scientific Name & Common Name & $\begin{array}{l}\text { Preference } \\
\text { Level }\end{array}$ \\
\hline Acanthaeceae & $\begin{array}{l}\text { Asystasia } \\
\text { gangetica }\end{array}$ & $\begin{array}{l}\text { Tropical } \\
\text { Primrose, } \\
\text { Hunter's weed }\end{array}$ & ++++ \\
\hline Commelinaceae & Conmelina diffusa & $\begin{array}{l}\text { Spreading day } \\
\text { flower }\end{array}$ & ++++ \\
\hline & $\begin{array}{l}\text { Chromoleaena } \\
\text { odorata }\end{array}$ & Awolowo's weed & + \\
\hline Asteraceae & Emilia sonchifolia & Shraving brash & ++++ \\
\hline Poaceae & Eleusine indica & $\begin{array}{l}\text { Bull Grass; } \\
\text { Goose grass }\end{array}$ & ++++ \\
\hline Musaceae & Panicum laxum & $\begin{array}{l}\text { Water bamboo } \\
\text { grass }\end{array}$ & ++++ \\
\hline Dryopteridaceae & $\begin{array}{l}\text { Nephrolepis } \\
\text { undulata }\end{array}$ & Sword fern & +++ \\
\hline Nymphaeaceae & $\begin{array}{l}\text { Nymphaea } \\
\text { odorata }\end{array}$ & Water lily & ++++ \\
\hline Amaranthaceae & $\begin{array}{l}\text { Pandiaka } \\
\text { involucrata }\end{array}$ & $\begin{array}{l}\text { Velvet bush } \\
\text { willow }\end{array}$ & ++ \\
\hline
\end{tabular}

Table 4: Plant species fed to T. senegalensis and their preference level. (Keys: ++++: High, +++: Moderate, ++: Low, +: Uncertain)

\section{Discussion}

The water temperature was within stipulated ranged as recommenced safe for aquatic fauna. This result is similar to Perrin et al. [9] that West African manatees are limited to waters temperature of $18^{\circ} \mathrm{C}$ and $27^{\circ} \mathrm{C}$, while Worthy et al. [4] also reported that manatee limited to water temperature value of $27^{\circ} \mathrm{C}$ will eat properly, increase in weight, and become nourished and mature fast. The $\mathrm{pH}$ range shows that the stream is tending towards alkalinity. This suggests that the stream is good for fish production. The dissolved oxygen value for the stream was high. The high dissolved oxygen level could be due to

exposure to enough sunlight and atmospheric air resulting in an increase in the rate of photosynthesis by the submerged plants in the water. Similar findings of high dissolved oxygen were reported by Williams et al. [12].

The manatee; Trichechus senegalensis exhibited different behaviours such as feeding and resting which are similar to those exhibited in the wild. Although, it reframe from surface feeding and bottom resting as human disturbance increased, but however, adapted to present condition in the semi-wild environment. Hartman et al. [13] reported that the behavioural activities of the West African manatee consist of feeding, resting, idling, travelling and socializing. Horikoshi et al. [14] also noted that the performance of these behaviours depend upon efficiency and availability of energy and nutrient intake.

The canal (holding facility for the manatee) is devoid of luxuriant aquatic vegetation except those sought for in the semi-wild environment. The manatee fed on any plant soft enough to be torn by the muscular upper lip and exhibited two feeding behaviours. First, rooting, where virtually the entire plant is consumed and second, grazing, where only leaves are eaten without consuming the roots. The manatee preferred certain species of plants to others based on taste and nutritional value. According to Robert et al. [15], the manatee's mode of nutrition (herbivore) indicates that the manatee is low on the food chain (i.e. primary consumer) of freshwater ecosystem.

The low time interval taken by the manatee to hold its breath while submerged and surface for air agrees with Reynolds et al. [16], that smaller and active manatee cannot stay under water for longer time and needs to breathe every two to three minutes [17].

The morphometric measurement indicates that the manatee has increased in body size and weight. The result also suggests that the manatee is a calf and conform with Odell et al. [18] that manatee calves range in total length of $1.6 \mathrm{~m}(160 \mathrm{~cm})$ to $1.8 \mathrm{~m}(180 \mathrm{~cm})$ and weight $270 \mathrm{~kg}$.

\section{Conclusion}

The little stream is threatened by anthropogenic activities such as washing of cloths and motorcycle, and sand mining. There is urgent need to closely monitor these activities in other to properly incorporate the manatee into the semi-wild environment.

\section{References}

1. Husar SL (1978) Trichechus senegalensis. American Society of Mammalogists 89: 1-3.

2. Reynolds III JE, Odell DK (1991) Manatees and Dugongs. Facts on File, Inc, Newyork.

3. IUCN (2006) IUCN Red List.

4. Lefebvre LW, Reid JP, Kenworthy WJ, Powell JA (2000) Characterizing manatee habitat use and seagrass grazing in Florida and Puerto Rico: implications for conservation and management. Pacific Conservation Biology 5: 289-298.

5. Happold DCD (1987) The mammals of Nigeria. Oxford Science Publications 4: 225-226.

6. Deutsch CJ (2000) Winter movements and use of warm-water refugia by radio-tagged West Indian manatees along the Atlantic coast of the United States. Final Report. Florida Power and Light Company and U.S. Geological Survey, Gainesville, Florida, USA.

7. Deutsch CJ, Reid JP, Bonde RK, Easton DE, Kochman HI et al. (2003) Seasonal movements, migratory behavior, and site fidelity of West Indian 
Citation: Esenowo IK, Akpan UA, Egwali EC (2014) The Behavioural and Morphometric Features of West African Manatee: Trichechus senegalensis in a Semi-Wild Environment. J Biodivers Endanger Species 2: 129. doi:10.4172/2332-2543.1000129

Page 4 of 4

manatees along the Atlantic coast of the United States. Wildlife Monographs 51: 1-77.

8. Antonio A, Mignucci-Giannoni R, Montoya-Ospina A, Mario V (2003) Status of Semi-captive manatee in Jamaica. LAJAM 2: 7-12.

9. Perrin WF (2001) Conservation status of the West African Manatee. Sirenews 36: 34-40.

10. Rathbun GB (1984) Sirenians. Pages 537-547 in S. Anderson and J. K. Jones, Jr. eds. Orders and Families of recent mammals of the world. John Wiley and sons, Inc. New York.

11. APHA, AWWA, WEF, (1998) Standard Methods for the Examination of Water and Wastewater. Greenberg. A. E., Clesceri, L. S. and Eaton, A. O. (eds) 20th Edition.

12. Martin P, Bateson P (1998) Measuring behaviour; An Introductory Guide. Cambridge University Press. Cambridge, 20-37pp.

13. William AA (1998) Investigating aquatic ecosystem. Prentice Hall Canada Inc. Scar borough, Ontario 83: 95.
14. Hartman DS (1979) Ecology and behaviour of the manatee (Trichecius manatus) in Florida. American society of mammalogists 5: 153.

15. Horikoshi C (2004) Effect of Hormonal and temporal factors on captive Female manatee (Trichechus manatus latrostris) Behaviours. Unpublished.

16. Robert C, Smith GW, Packard JM, LaCommare KS (2004) Seasonal occurrence of male Antillean manatees (Trichechus manatus manatus) on the Belize Barrier Reef. Aquatic Mammals 29: 342-254.

17. Reynolds III JE (2000) Possible locations for long-term warm-water refugia for manatees in Florida: alternatives to power plants. Final Report prepared for the Department of Environmental Services, Florida. Florida Power and Light Company, Juno, Florida.

18. Odell DK (1982) The West Indian manatee Trichechus manatus Linnaeus: 828-837 in Chapman JA and Feldhamer GA (eds.) Wild Mammals of North America. Johns Hopkins University Press, Baltimore. 